(c) American Dairy Science Association, 2003.

\title{
Intestinal Morphology, Epithelial Cell Proliferation, and Absorptive Capacity in Neonatal Calves Fed Milk-Born Insulin-Like Growth Factor-I or a Colostrum Extract ${ }^{1}$
}

\author{
B. Roffler, ${ }^{\star, 2}$ A. Fäh, ${ }^{\star, 3}$ S. N. Sauter, ${ }^{*}$ H. M. Hammon, ${ }^{*}$ P. Gallmann, $\dagger$ G. Brem, $\ddagger$ and J. W. Blum ${ }^{\star}$ \\ *Division of Animal Nutrition and Physiology, \\ Institute of Animal Genetics, Nutrition and Housing, \\ Faculty of Veterinary Medicine, University of Berne, CH-3012 Berne, Switzerland \\ †Swiss Federal Dairy Research Station, CH-3097 Liebefeld-Berne, Switzerland; \\ ¥Institute for Agrobiotechnology, Department of Biotechnology in Animal Production, \\ University of Veterinary Medicine, A-1210 Vienna, Austria.
}

\begin{abstract}
Concentrations of nonnutritional factors, such as insulin-like growth factor-I (IGF-I), in bovine colostrum are high and can modulate neonatal gastrointestinal tract development and function. In neonatal calves, we have investigated effects on intestinal epithelial cell morphology, proliferation, and absorption of feeding milk-born human IGF-I (hIGF-I) or a bovine colostrum extract. Calves were fed a milk-based formula containing amounts of nutrients comparable to colostrum for the first $3 \mathrm{~d}$ and a milk replacer from $\mathrm{d}$ 4 on. Formula and milk replacer contained only traces of nonnutritional factors. In experiment 1 , supraphysiological amounts of hIGF-I (3.8 mg/L formula; secreted by transgenic rabbits with their milk) were added to the formula. Xylose appearance in blood (after feeding xylose on $\mathrm{d} 5$ ) and intestinal traits (after euthanasia on $d$ 8) did not differ between groups. In experiment 2, an extract of first-milked bovine colostrum that provided physiological amounts of IGF-I $(0.50,0.15$, and $0.09 \mathrm{mg}$ of IGF-I/L formula on $\mathrm{d} 1$, 2 , and 3 , respectively, and $0.09 \mathrm{mg}$ of IGF-I/L milk replacer on $\mathrm{d} 4$ ) was added to formula or milk replacer. Plasma xylose concentration in the control group was transiently higher than in calves fed the colostrum extract. On d 5 (after euthanasia), villus circumferences and heights in small intestine, and epithelial cell proliferation rate in intestine were higher in calves fed the colostrum extract than in controls. In
\end{abstract}

\footnotetext{
Received August 14, 2002.

Accepted October 22, 2002

Corresponding author: J. W. Blum; e-mail: juerg.blum@itz. unibe.ch.

${ }^{1}$ Supported in part by Swiss National Science Foundation (Grant Nr. 32-51012.97).

${ }^{2}$ Part of a thesis for Dr. med. vet., accepted by the Faculty of Veterinary Medicine, University of Berne, 2001.

${ }^{3}$ Part of a thesis for Dr. med. vet., accepted by the Faculty of Veterinary Medicine, University of Berne, 2000.
}

conclusion, orally administered hIGF-I from transgenic rabbits had no effect on the intestinal tract. However, feeding a bovine colostrum extract enhanced intestinal villus size, although it appeared to transiently decrease the absorptive capacity.

(Key words: hormone, growth factor, intestine, newborn)

Abbreviation key: bCE = bovine colostrum extract; BrdU = 5-bromo-2'-deoxyuridine; $\mathbf{C F}=$ crude fat; $\mathbf{G E}$ = gross energy; $\mathbf{G H}=$ growth hormone; $\mathbf{G I}$ = gastrointestinal; GIT = GI tract; $\mathbf{G r C}_{\mathbf{1}}=$ group that served as control in experiment 1 and was fed a milk-based formula from d 1 to $\mathrm{d} 3$ and then a milk replacer; $\mathbf{G r C}_{2}$ = group that served as control in experiment 2 and was fed a milk-based formula from $d 1$ to 3 and then a milk replacer; $\mathbf{G r E}=$ group fed in experiment 2 as calves of $\mathrm{GrC}_{2}$ but furthermore a bCE that was added to formula and milk replacer; GrI = group fed in experiment 1 the same amounts of formula and milk replacer as calves of $\mathrm{GrC}_{1}$, but furthermore hIGF-I that was added to formula and $\mathrm{MR}_{1}$; hIGF-I = human IGFI; IGFBP = IGF binding protein; $\mathbf{M R}=$ milk replacer; $\mathbf{N f E}=$ nitrogen-free extracts; $\mathbf{T}_{\mathbf{3}}=3.5 .3^{\prime}$-triiodothyronine; $\mathbf{T}_{4}=$ thyroxine.

\section{INTRODUCTION}

Whereas the fetus receives nutrients mainly parenterally, the newborn suddenly depends on oral intake. Around birth, major changes in intestinal growth and differentiation of gastrointestinal (GI) epithelial cells, and digestive and absorptive capacities of the GI tract (GIT) occur, which are controlled by intrinsic (genetic programming) and extrinsic factors (intestinal flora, hormonal, neuronal, nutritional and nonnutritional factors), as reviewed by Lipkin (1981), Pacha (2000), and Sangild (2001).

Although contents of energy, protein, fat and some minerals are well known to be markedly higher in 
colostrum than in mature milk, it is thought that effects of these (nutritional) components are not the only factors that can enhance postnatal GIT development. Thus, various nonnutritional proteins and peptides, such as hormones, growth factors, and cytokines are present in much higher concentrations in colostrum than in mature milk and are supposed to modify early postnatal development of the GIT (Odle et al., 1996; Blum and Hammon, 2000; Sangild, 2001).

In bovine colostrum IGF-I is present in high concentrations at the end of pregnancy, and the greatest mass is available at the start of lactation (Campana and Baumrucker, 1995). IGF-I is known to be an important mediator of growth and differentiation and is produced in many tissues, but mainly in the liver, as shown in 1- and 8-d old calves (Cordano et al., 1998; 2000; Pfaffl et al., 2002). Ingested IGF-I is barely absorbed and thus has barely systemic effects in the neonatal calf (Baumrucker et al., 1994a; Vacher et al., 1995; Hammon and Blum, 1997b) and pigs (Burrin et al., 1996; Odle et al., 1996). However, GIT effects of fed IGF-I, such as increased intestinal mucosal growth or DNA synthesis, have been demonstrated (Baumrucker et al., 1994a; Steeb et al., 1995; Burrin et al., 1999). Effects are mediated by IGF type-I receptors and possibly by insulin receptors that (besides IGFII receptors) are synthesized and are present in the small intestine and colon of 1- and 8-d old calves (Baumrucker et al., 1994a; Hammon and Blum, 2002; Pfaffl et al., 2002; Georgiev et al., 2003) and in other species. The situation is complex because IGF-I is also produced in the small intestine as shown in 1- and 8-d old calves (Cordano et al., 1998, 2000; Pfaffl et al., 2002) and circulates in blood in amounts dependent on nutrition and ontogenetic state (Hadorn et al., 1997; Hammon and Blum, 1997b; Rauprich et al., 2000). In addition, besides colostral IGF-I, other nonnutritive biological active factors are present in bovine colostrum (Campana and Baumrucker, 1995) and may promote the neonatal GIT development in a synergistic manner.

Two studies were conducted to investigate the importance of milkborne bioactive factors on the development of the GIT of neonatal calves. In the first experiment, the studies focused on effects of feeding human IGF-I (hIGF-I), which has the same amino acid sequence as bovine IGF-I and that was secreted into the milk by transgenic rabbits (Brem et al., 1994), and in the second experiment, the emphasis was on studying effects of feeding an extract that originated from bovine colostrum (bCE) and contained mainly nonnutritional factors (such as IGF-I).

\section{MATERIALS AND METHODS}

\section{Animals, Husbandry, Feeding, Experimental Procedures and Evaluation of Health Status}

The experimental procedures followed the actual Swiss law on animal protection and were approved and supervised by the Committee for the Permission of Animal Experiments of the Canton of Freiburg, GrangesPaccot, Switzerland after approval by the Swiss Federal Veterinary Administration, Liebefeld-Berne. Calves were single born after normal lengths of pregnancy and normal parturition at the Research Station (Posieux, Switzerland) or at neighboring farms, were then separated immediately from their dams, and held unattached on straw in wooden boxes $(100 \times 170 \mathrm{~cm})$.

In experiment 1, 14 male calves (seven Simmental $\times$ Red Holstein, five Holstein Friesian, and two Braunvieh $\times$ Brown Swiss) were studied. Calves of group $\mathrm{C}_{1}$ $\left(\mathbf{G r C}_{1}\right)$ served as control and were fed twice daily a milk-based formula (30, 40 and $50 \mathrm{~g} / \mathrm{kg}$ of BW) on d 1, 2, and 3 , respectively and then twice daily a milk replacer (MR; $50 \mathrm{~g} / \mathrm{kg}$ of BW) up to d 7. Calves of group I (GrI) were fed the same amounts of formula and MR as calves of $\mathrm{GrC}_{1}$, but were furthermore fed hIGF-I $(3.8 \mathrm{mg} / \mathrm{L}$ of formula or MR) that was added to formula and MR. The hIGF-I was from milk of transgenic rabbits coding for hIGF-I in the alveolar cells of the mammary gland (Brem et al., 1994). Wolf et al. (1997) showed that hIGFI in milk is biologically active. With $260 \mathrm{mg} / \mathrm{L}$, the concentration of IGF-I in rabbit milk was more than 500 times higher than the concentration of IGF-I in bovine colostrum at the onset of lactation $(0.3$ to $0.5 \mathrm{mg} / \mathrm{L})$ (Blum and Hammon, 2000). According to Brem et al. (1994) rabbit milk also contained IGFBP-2, but this could not be confirmed in own studies. The rabbit milk per kilogram contained $324 \mathrm{~g}$ of DM, $120 \mathrm{~g}$ of CP, 165 $\mathrm{g}$ of crude fat (CF), $20 \mathrm{~g}$ of nitrogen-free extracts, and $19 \mathrm{~g}$ of crude ash.

In experiment 2, 14 male calves (three Braunvieh $\times$ Brown Swiss, eight Holstein Friesian, three Simmental $\times$ Red Holstein) were studied. Calves of group $\mathrm{C}_{2}\left(\mathbf{G r C}_{2}\right)$ served as control and were fed twice daily a milk-based formula (30, 40, and $50 \mathrm{~g} / \mathrm{kg}$ of BW) on d 1, 2, and d 3 and twice on d 4 a MR ( $50 \mathrm{~g} / \mathrm{kg}$ of BW). Calves of group $\mathrm{E}(\mathbf{G r E})$ were fed as calves of $\mathrm{GrC}_{2}$ but were furthermore fed a bCE that was added to formula and MR $(0.23,0.07,0.04$, and $0.04 \mathrm{~g} / \mathrm{L}$ formula or MR on d 1,2 , 3 , and 4 , respectively).

The bCE was prepared at the Swiss Federal Dairy Research Station, Berne-Liebefeld from a pool of 246 $\mathrm{L}$ of first-milked bovine colostrum. The procedure (a) necessitated dilution of the colostrum with water (1:6, $\mathrm{vol} / \mathrm{vol}$ ) due to the high protein content (120 to $160 \mathrm{~g} /$ $\mathrm{kg}$ ) that blocked pores of UF membranes, (b) included 
Table 1. Composition of bovine colostrum extract (bCE) fed to $\mathrm{GrE}$ in experiment 2.

\begin{tabular}{|c|c|}
\hline Trait & $\begin{array}{l}\text { bCE, original } \\
\text { substance }\end{array}$ \\
\hline Water, g/kg & 904 \\
\hline DM, g/kg extract & 95.6 \\
\hline Gross energy, MJ/kg extract (MJ/kg DM) & $1.9(19.7)$ \\
\hline Immunoglobulin G, g/L extract (g/kg DM) & $4.16(44.16)$ \\
\hline $\mathrm{CP}, \mathrm{g} / \mathrm{kg}$ extract $(\mathrm{g} / \mathrm{kg} \mathrm{DM})^{1}$ & $65.9(689)$ \\
\hline Whey proteins, g/kg extract (g/kg DM) & $62.7(656)$ \\
\hline Casein, $\mathrm{g} / \mathrm{kg}$ extract $(\mathrm{g} / \mathrm{kg} \mathrm{DM})$ & $3.2(33)$ \\
\hline Nonprotein nitrogen, g/kg extract (g/kg DM) & $7(73.2)$ \\
\hline Crude fat, $g / k g$ extract (g/kg DM) & $0.3(3.2)$ \\
\hline Nitrogen free extracts, g/kg extract (g/kg DM) & $16.5(172.8)$ \\
\hline Urea, $\mathrm{mmol} / \mathrm{L}$ extract & 2.16 \\
\hline Lactose, g/kg extract (g/kg DM) & $11(115)$ \\
\hline Crude ashes, g/kg extract (g/kg DM) & $5.9(61.8)$ \\
\hline Calcium, g/L extract (g/kg DM) & $0.39(4.09)$ \\
\hline Inorganic phosphorus, g/L extract (g/kg DM) & $0.52(5.51)$ \\
\hline Magnesium, g/L extract (g/kg DM) & $0.14(1.53)$ \\
\hline Insulin-like growth factor-I, $\mu \mathrm{g} / \mathrm{L}$ extract & 2,185 \\
\hline Insulin-like growth factor binding protein 2, O.D. ${ }^{2}$ & 7,356 \\
\hline Insulin-like growth factor binding protein 3, O.D. & 56,546 \\
\hline Insulin, $\mu \mathrm{g} / \mathrm{L}$ extract & 35 \\
\hline Glucagon, ng/L extract & 88 \\
\hline Growth hormone & n.m. ${ }^{3}$ \\
\hline Cortisol, nmol/L extract & 3.24 \\
\hline Lactoferrin, mg/L extract & 151 \\
\hline Cortisol, nmol/L extract & 3.24 \\
\hline 3.5.3'-Triiodothyronine, $\mathrm{nmol} / \mathrm{L}$ extract & 0.34 \\
\hline
\end{tabular}

acidification with citric acid $(300 \mathrm{~g} / \mathrm{L})$ to $\mathrm{pH} 4.8$ to 5.3 for $1 \mathrm{~h}$ for (partial) separation of growth factors (such as IGF-I) from binding proteins, (c) elimination of casein with common cheese making techniques (including use of recombinant chymosin) and of Ig, (d) and elimination of large-molecular whey proteins with a combination of heat $\left(79^{\circ} \mathrm{C}, 45 \mathrm{~s}\right)$, (e) followed by several UF steps using a TETRA-processor (Tetra Pak Filtration Systems, Denmark). The first UF step was performed with a $100-\mathrm{kDa}$ module to eliminate casein and Ig. The second and third UF steps were performed with a $1-\mathrm{kDa}$ module and a $3-\mathrm{kDa}$ module, respectively, to eliminate water, lactose, salts, and ashes. The procedure was optimized in the course of several preexperiments to extract up to $50 \%$ of the original IGF-I as the leading substance. The contents of bCE are shown in Table 1.

All calves were fed three differently composed milkbased formulas on $\mathrm{d} 1,2$, and 3 and MR from $\mathrm{d} 4$ to 7 in experiment 1 and on $\mathrm{d} 4$ in experiment 2. Calves were fed twice daily by bottle. In experiment 1 , the first meal was given at $3.6 \pm 0.4 \mathrm{~h}$ and at $3.1 \pm 0.5 \mathrm{~h}$ after birth in $\mathrm{GrC}_{1}$ and GrI, respectively, and in experiment 2 , calves received the first meal at $3.3 \pm 0.9 \mathrm{~h}$ and at $2.7 \pm 0.6 \mathrm{~h}$ after birth in $\mathrm{GrC}_{2}$ and $\mathrm{GrE}$, respectively. The ensuing feedings were at 8,24 , and $32 \mathrm{~h}$ after the first meal. From d 3 on, calves were fed daily at 0800 and at $1600 \mathrm{~h}$. In both studies, calves were pair-fed so that there were no differences in energy and nutrient intakes between groups within experiments 1 and 2 .

Formulas for meals on $\mathrm{d} 1,2$, and 3 contained amounts of nutrients (protein, fat, nitrogen-free extracts, i.e., especially lactose), which were in the range of contents that can be measured in colostrum on $d 1$ (milking 1), 2 (milking 3), and 3 (milking 5) of lactation, respectively. Formulas were produced by UFA AG (Sursee, Switzerland) and consisted of calcium-caseinate (Emmi Milch AG, Lucerne, Switzerland), lactalbumin 90 (Emmi Milch AG, Lucerne, Switzerland), lactose (UFA AG, Sursee, Switzerland) and a premix containing vitamins and minerals (Provimi S. A., Cossonay-Gare, Switzerland). The three formulas were dissolved by adding water and double milk cream (Agricultural Institute of the Canton of Freiburg, Grangeneuve, Switzerland) and were stored in plastic bottles at $-20^{\circ} \mathrm{C}$. At feeding time, bottles were quickly warmed up to $40^{\circ} \mathrm{C}$ and calves were then fed immediately. The MR ("UFA 200 Natura", without antibiotics; UFA AG, Sursee, Switzerland) was prepared as a $100 \mathrm{~g} / \mathrm{L}$ solution. Contents of different formulas for experiment 1 and 2 and of MR are shown in Table 2. The slightly enhanced nutrient and energy intakes in test groups GrI and GrE by added rabbit milk (experiment 1) or 


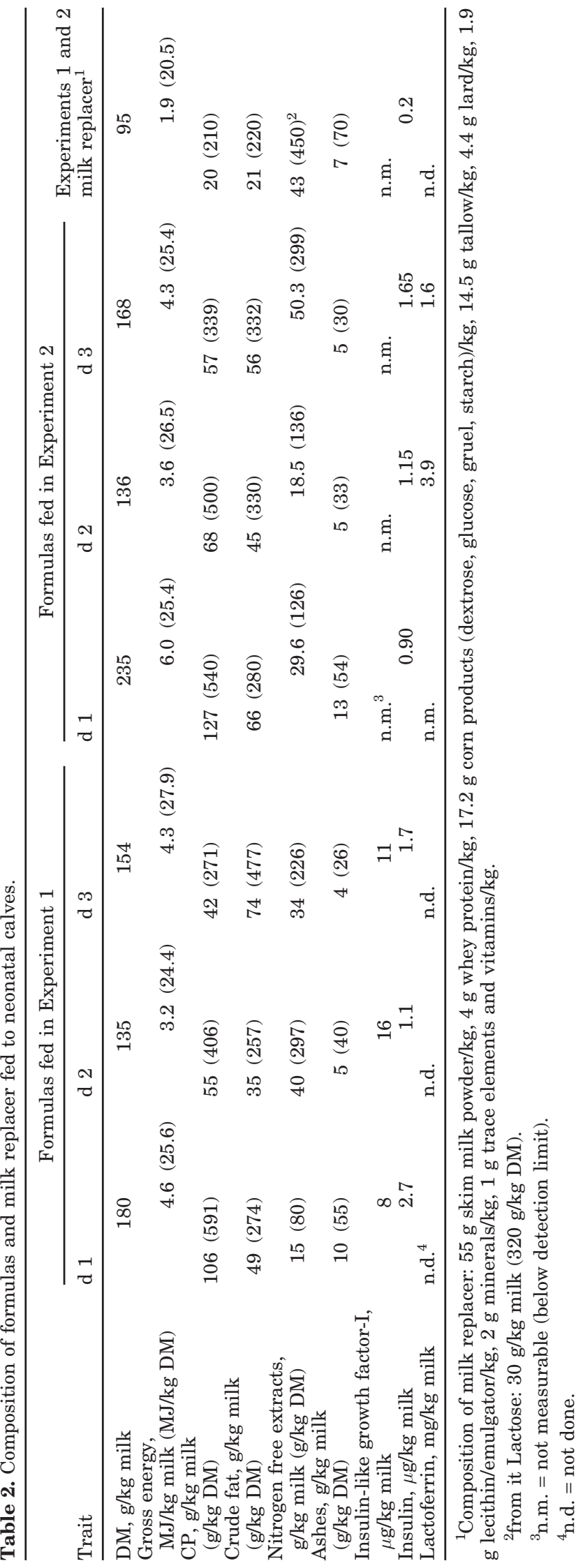

extract (experiment 2) in control groups $\mathrm{GrC}_{1}$ and $\mathrm{GrC}_{2}$ were compensated by adding corresponding amounts of formula of $\mathrm{d} 1$.

To study the intestinal xylose absorption, $0.5 \mathrm{~g} / \mathrm{kg}$ $\mathrm{BW}$ of d-xylose were added to the morning meal on $\mathrm{d}$ 5 in experiment 1 and on $d 3$ in experiment 2 .

Calves were injected s.c. $2 \mathrm{~g}$ of a bovine colostral Ig preparation (Gammaserin, containing $100 \mathrm{~g}$ of $\mathrm{IgG} \mathrm{g} /$ L; Gräub AG, Berne, Switzerland) before first feed intake. In addition, calves were fed chicken-egg-derived Ig containing high antibody titers against rotavirus and Escherichia coli type K 99 (Globigen 88; kindly donated by Lohmann Animal Health, Cuxhaven, Germany), but no bovine IGF-I. Fed amounts per meal of chicken-eggderived Ig were $10 \mathrm{~g}$ on $\mathrm{d} 1,8 \mathrm{~g}$ on $\mathrm{d} 2,6 \mathrm{~g}$ on $\mathrm{d} 3$, and $4 \mathrm{~g}$ on $\mathrm{d} 4 \mathrm{in}$ both experiments and $2 \mathrm{~g}$ on $\mathrm{d} 5$ to $7 \mathrm{in}$ experiment 1 . From d 1 to d 3, calves were daily s.c. injected antibiotics $(0.5 \mathrm{ml}$ of Baytril $5 \%$ per $10 \mathrm{~kg}$ of BW; Bayer AG, Leverkusen, Germany). Navels were disinfected after birth to protect calves from infection.

Rectal temperature was measured daily and fecal consistency was scored daily (normal, thin, or watery). Body weight was measured on 1 and 8 of life in experiment 1 , and on $d 1$ and 5 in experiment 2 .

\section{Laboratory Analyses}

Blood analyses. Blood samples were taken on d 5 in experiment 1 and on $\mathrm{d} 3$ in experiment 2 before $(0$ h) and at $0.5,1,2,3,4,5,6,7,8$, and $24 \mathrm{~h}$ after the morning feeding to determine xylose concentrations. Tubes were put on crushed ice until centrifuged at 1000 $\times g$ for $20 \mathrm{~min}$. Supernatants were aliquoted and stored at $-20^{\circ} \mathrm{C}$. D-Xylose was measured as described by Hammon and Blum (1997a).

Analyses in formula, milk replacer, rabbit milk and colostrum extract. Samples of formula 1, 2, and 3 and aliquots of rabbit milk and bCE were lyophilized to determine DM, CP (by the Kjeldahl method), crude fat (CF; by Soxhlet extraction), and ashes (after combustion at $550{ }^{\circ} \mathrm{C}$ ) using standard procedures at the Swiss Federal Research Station for Animal Production (Posieux, Switzerland). Contents of nitrogen-free extracts (NfE) and gross energy (GE, based on energy equivalents of $36.6,17.0$, and $24.2 \mathrm{MJ} / \mathrm{kg}$ for $\mathrm{CL}, \mathrm{NfE}$, and $\mathrm{CP}$, respectively) were calculated. Information on contents of MR was provided by the producer. Concentrations of IGF-I in rabbit milk and of IGF-I and insulin in bCE and in formulas and MR were analyzed as described by Hammon and Blum (1997b). In addition, in $\mathrm{bCE}$, concentrations of calcium, phosphate and magnesium were measured by atomic absorption spectrophotometry at the Federal Research Station for Animal 
Production, Posieux, Switzerland. Concentrations of casein, LA, LG, and lactose were determined at the Swiss Federal Dairy Research Station (Liebefeld-Berne). The IgG concentration was determined by ELISA (Erhard et al., 1995). Concentrations of growth hormone, glucagon, cortisol, 3.5.3'-triiodothyronine $\left(\mathbf{T}_{3}\right)$ and thyroxine $\left(\mathbf{T}_{4}\right)$ were determined by radioimmunoassay and urea were determined at the Division of Animal Nutrition and Physiology as described (Rauprich et al., 2000). Lactoferrin concentration in bCE was determined by ELISA using an antibovine serum that was kindly donated by F. Schanbacher, Ohio State University, Wooster, and a highly purified (97\%) bovine lactoferrin that was kindly donated by DMV International, Veghel, The Netherlands. Amounts of IGF-binding proteins (IGFBP) in bovine and rabbit milks and formulas were measured as described by Hammon and Blum (1997b). A cow blood plasma served as control with which the blots were compared to obtain relative IGFBP concentrations.

Analyses in drugs. Concentrations of IGF-I in Globigen 88 and Gammaserin were measured as described for plasma. The IGF-I concentration in Globigen 88 was below the detection limit, whereas Gammaserin contained $288 \mu \mathrm{g}$ of IGF-I/L.

\section{Histology, Histomorphometry, and Cell Proliferation of Intestinal Mucosa}

After slaughtering calves on d 8 (experiment 1) and 5 (experiment 2), the GIT was removed. Tissue samples (about $4 \mathrm{~cm} \times 4 \mathrm{~cm}$ ) from mid duodenum, mid jejunum, mid ileum, and mid colon were removed, stuck onto a piece of cork and transferred into a phosphate-buffered paraformaldehyde (40 g/L) solution (Bühler et al., 1998; Blätttler et al., 2001). After $24 \mathrm{~h}$, three 1-mm thick cross-sectional pieces were cut from each sample and embedded in a paraffin block. Ten cuts of 3- to $4-\mu \mathrm{m}$ thick sections were made of each block, resulting in 30 different tissue samples per intestinal site and calf. For histomorphometrical analyses, three slides of different regions were taken from each paraffin block, put onto Super Frost slides and stained with hematoxylin and eosin. Large size vacuoles, which are typical for immature fetal enterocytes, were searched in each part of small intestine. Morphometric analyses were conducted with a Zeiss light microscope connected to a videobased, computer-linked system that was programmed to perform morphometrical analyses (Bühler et al., 1998; Blättler et al., 2001). Quantitative measurements were made in at least 30 lengthwise cut, well-oriented crypt-villus preparations for each intestinal sample. Villus circumferences and heights, as well as crypt depths and (in experiment 2) submucosa thickness were evaluated. The coefficient of variation for villus circum- ferences, heights, and crypt depths was $<20 \%$ if at least 30 villi and crypts in the small intestine or crypts in the colon were evaluated (Bühler et al., 1998).

Cell proliferation was based on counting cells that incorporated 5-bromo-2'-deoxyuridine (BrdU; Boehringer $\mathrm{GmbH}$, Mannheim, Germany) into DNA of crypt cells, as shown in calves (Blättler et al., 2001). Calves were administered $500 \mathrm{mg}$ of BrdU intravenously, dissolved in $20 \mathrm{ml}$ of PBS, 60 min before slaughtering on d 8 (experiment 1 ) or on d 5 (experiment 2). Monoclonal anti-BrdU antibody (\# 1170 376, from Boehringer $\mathrm{GmbH}$, Mannheim, Germany) was added to slides of intestinal tissue sections, and BrdU incorporation was visualized with biotinylated goat anti-mouse Ig (Dako A/S, Zug, Switzerland), streptABComplex/AP-kit (Dako A/S, Zug, Switzerland) and Fast Red TR/Naphtol ASMX (Sigma Chemical Co., Saint Louis, MO). In experiment 1, 2000 intestinal epithelial cells were counted of each calf and intestinal site and BrdU-labeled (epithelial) cells relative to unlabeled as well as BrdU-labeled (epithelial) cells per length $(\mathrm{mm})$ of mucosal epithelial layer were calculated, thus resulting in ratios of mitotic (epithelial) cells per total epithelial cells and the number of mitotic (epithelial) cells per millimeter of epithelial cells, respectively. In addition, in experiment 2, labeled and unlabeled cells of 10 crypts of each calf and intestinal site were counted. The BrdU-labeled crypt cells relative to unlabeled crypt cells were calculated, thus resulting in ratios of mitotic (epithelial) crypt cells per total crypt cells.

\section{Statistical Procedures}

Values of BW, rectal temperature, plasma xylose concentrations, and histomorphometrical and histoproliferative values were expressed as means \pm SEM. For $\mathrm{BW}$, rectal temperature, and plasma xylose the model used was $\mathrm{Y}_{\mathrm{ijkl}}=\mu+$ treatmenti + calf $_{\mathrm{ij}}+$ time $_{\mathrm{k}}+$ (treatment $\times$ time $)_{i k}+e_{i j k l}$, where $Y_{i j k l}=$ measured value, $\mu=$ general mean, treatment $t_{i}=$ feeding of hIGF-I in experiment 1 or bCE in experiment 2 , calf $_{\mathrm{ij}}=$ individual calf nested for treatment, time $\mathrm{k}_{\mathrm{k}}=$ time of data sampling, treatment $\times$ time $_{\mathrm{ik}}=$ interaction between treatment and time, $\mathrm{e}_{\mathrm{ijkl}}=$ residual error. For histomorphometrical and histoproliferative data in the small intestine, the model used was $\mathrm{Y}_{\mathrm{ijkl}}=\mu+$ treatment $_{\mathrm{i}}+$ calf $_{\mathrm{ij}}+$ gut segments $_{\mathrm{k}}$ $+(\text { treatment } \times \text { gut segments })_{i k}+e_{i j k l}$, where $Y_{i j k l}=$ measured value, $\mu=$ general mean, treatment $t_{i}=$ feeding of hIGF-I in experiment 1 and of bCE in experiment 2 , calf $_{\mathrm{ij}}=$ individual calf nested for treatment, gut segments $_{\mathrm{k}}=$ different gut segments, treatment $\times$ gut segments $_{\mathrm{ik}}=$ interaction between treatment and gut segments, $\mathrm{e}_{\mathrm{ijkl}}=$ residual error. Data were analyzed, using the RANDOM (calf) and REPEATED (time or 
gut segments) methods of the MIXED procedure (SAS, 1996). Treatment, time, and gut segment differences were localized by the ESTIMATE statement of SAS, using Bonferroni $t$ test $(P<0.05)$. In colon, treatment differences (hIGF-I in experiment 1, bCE in experiment 2 ) were analyzed by Student's $t$-test (SAS, 1996). For correlation between villus height and cell proliferation rate, the CORR procedure of the SAS program (SAS, 1996) was used.

\section{RESULTS}

\section{Feed Intakes, BW, Rectal Temperatures, and Fecal Scores}

Experiment 1. Calves of both groups were pair-fed and ate all provided feeds. The BW of calves of $\mathrm{GrC}_{1}$ and $\mathrm{GrI}$ were similar $\left(\mathrm{GrC}_{1}: 45.9 \pm 1.6\right.$ and $44.7 \pm 2.2$ $\mathrm{kg}$ on $\mathrm{d} 1$ and 8, respectively; GrI: $45.4 \pm 2.2$. and 43.9 $\pm 1.9 \mathrm{~kg}$ on $\mathrm{d} 1$ and 8 , respectively). Rectal temperature was stable in $\mathrm{GrC}_{1}\left(38.9 \pm 0.1\right.$ and $38.9 \pm 0.1^{\circ} \mathrm{C}$ on $\mathrm{d} 1$ and 8 , respectively), but tended to rise $(P<0.1)$ from $\mathrm{d}$ 1 to 8 in $\mathrm{GrI}\left(38.6 \pm 0.1\right.$ and $38.9 \pm 0.1{ }^{\circ} \mathrm{C}$ on $\mathrm{d} 1$ and 8 , respectively). Calves were healthy, but most of them showed reduced fecal consistency from d 2 to 4 .

Experiment 2. Calves of both groups were pair-fed and ingested all provided feeds. The $\mathrm{BW}$ of $\mathrm{GrC}_{2}$ and $\mathrm{GrE}$ were similar $\left(\mathrm{GrC}_{2}: 46.8 \pm 1.2\right.$ and $48.1 \pm 2.4 \mathrm{~kg}$ on $\mathrm{d} 1$ and 5, respectively; GrE: $46.5 \pm 1.0$ and $48.0 \pm$ $2.4 \mathrm{~kg}$, respectively). Rectal temperatures increased ( $P$ $<0.01)$ similarly from d 1 to 4 in both groups $\left(\mathrm{GrC}_{2}\right.$ : $38.5 \pm 0.1$ and $39.3 \pm 0.1^{\circ} \mathrm{C}$ on $\mathrm{d} 1$ and 5 , respectively; GrE: $38.6 \pm 0.2$ and $39.5 \pm 0.2^{\circ} \mathrm{C}$ on $\mathrm{d} 1$ and 5 , respectively). Calves were healthy, but fecal consistency was reduced in both groups from $\mathrm{d} 2$ to 4 .

\section{Xylose Absorption Test}

Experiment 1. Plasma xylose concentrations increased $(P<0.001)$ from $0.3 \pm 0.03 \mathrm{mmol} / \mathrm{L}$ at time 0 in both groups to a maximum of $2.1 \pm 0.3 \mathrm{mmol} / \mathrm{L}$ (at 8 and $5 \mathrm{~h}$ in $\mathrm{GrC}_{1}$ and $\mathrm{GrI}$, respectively) after xylose intake. There were no significant group differences.

Experiment 2. Plasma xylose concentrations increased $(P<0.001)$ from $0.3 \pm 0.03 \mathrm{mmol} / \mathrm{L}$ at time 0 to a maximum $\left(2.9 \pm 0.1\right.$ and $2.7 \pm 0.2 \mathrm{mmol} / \mathrm{L}$ in $\mathrm{GrC}_{2}$ and $\mathrm{GrE}$, respectively) between 5 and $7 \mathrm{~h}$ after xylose intake. At 3 and $4 \mathrm{~h}$ after xylose intake plasma xylose concentrations were higher $(P<0.05)$ in $\mathrm{GrC}_{2}$ than in $\mathrm{GrE}$.

\section{Villus Circumferences, Areas and Heights, and Crypt Depths in the Small Intestine, Crypt Depths in the Colon and Proliferation of Intestinal Epithelial Cells in Calves}

Experiment 1. Histomorphometrical data in small intestine and colon and indexes of epithelial cell proliferation at the age of $8 \mathrm{~d}$ were similar in both groups.

Experiment 2. Vacuolated epithelial cells were seen at the top of the villi in the ileum of 1 calf in $\mathrm{GrC}_{2}$ and 1 calf in $\mathrm{GrE}$ and in duodenum of 2 other calves GrE. In total small intestine villus circumferences and heights were greater $(P<0.05)$ in $\mathrm{GrE}$ than in $\mathrm{GrC}_{2}$. The number of BrdU-labeled cells per millimeter of epithelial cells in ileum was greater $(P<0.05)$ in $\mathrm{GrE}$ than in $\mathrm{GrC}_{2}$. In total small intestine the number of BrdUlabeled cells per millimeter of epithelial cells tended to be greater $(P<0.1)$ in $\mathrm{GrE}$ than in $\mathrm{GrC}_{2}$. The ratios of BrdU-labeled cells per total epithelial cells and per total crypt cells were smaller $(P<0.05)$ in duodenum than in jejunum and ileum. The number of BrdU-labeled crypt cells per total crypt cells in colon tended to be greater $(P<0.1)$ in $\mathrm{GrE}$ than in $\mathrm{GrC}_{2}$.

\section{DISCUSSION}

\section{Feeding, Growth Performance, and Metabolic, Endocrine, and Health Status}

Although the amounts of nutrients fed with formulas during the first $3 \mathrm{~d}$ were not much different from those in bovine colostrum, BW did not increase during the first week of life, in agreement with other experiments with formula-fed calves (Rauprich et al., 2000). BW gain was also not influenced by hIGF-I or bCE intakes.

Metabolite and hormone concentrations were within physiological ranges (data not shown) and comparable to values in previous studies (Baumrucker et al., 1994a; Blum and Hammon, 2000; Rauprich et al., 2000). Therefore, ingested bioactive factors in GrI or GrE had no systemic metabolic and endocrine effects. Furthermore, possible group differences at the intestinal level were not due to differences in circulating concentrations of measured hormones, growth factors or metabolites. Rectal temperatures were always within the physiological range and as observed in previous studies (Hadorn et al., 1997; Rauprich et al., 2000).

\section{Histology, Histomorphometry, Proliferation of Intestinal Epithelial Cells, and Xylose Absorption Test}

General aspects. Because in experiment 2 there were only small numbers of vacuolated enterocytes, i.e., remnants of fetal enterocytes (on tips of villi in the 
Table 3. Histomorphometry and epithelial cell proliferation ${ }^{1}$ of the duodenum, jejunum, ileum, and colon in neonatal calves in experiment 1 fed formula and milk replacer with $(\mathrm{GrI})$ or without $\left(\mathrm{GrC}_{1}\right)$ hIGF-I, and in experiment 2 fed formula and milk replacer with $(\mathrm{GrE})$ or without $\left(\mathrm{GrC}_{2}\right)$ bovine colostrum extract.

\begin{tabular}{|c|c|c|c|c|}
\hline \multirow[b]{2}{*}{ Traits } & \multicolumn{2}{|c|}{ Experiment 1} & \multicolumn{2}{|c|}{ Experiment 2} \\
\hline & $\mathrm{CrC}_{1}$ & GrI & $\mathrm{GrC}_{2}$ & GrE \\
\hline \multicolumn{5}{|l|}{ Duodenum } \\
\hline Villus circumferences $(\mu \mathrm{m}) \times 10$ & $75 \pm 4$ & $80 \pm 5$ & $101 \pm 8$ & $116 \pm 6$ \\
\hline Villus heights $(\mu \mathrm{m}) \times 10$ & $26 \pm 2$ & $28 \pm 2$ & $40 \pm 4$ & $48 \pm 3$ \\
\hline Crypt depths $(\mu \mathrm{m}) \times 10$ & $27 \pm 1$ & $27 \pm 1$ & $13 \pm 1$ & $15 \pm 1$ \\
\hline Submucosa thickness $(\mu \mathrm{m}) \times 10$ & n.d. ${ }^{2}$ & n.d. & $15 \pm 2$ & $14 \pm 2$ \\
\hline BrdU labeled crypt cells/total crypt cells $\times 100$ & n.d. & n.d. & $12.9 \pm 2$ & $11.4 \pm 1$ \\
\hline BrdU labeled cells/total epithelial cells × 100 & $11.8 \pm 1$ & $11.3 \pm 1$ & $4.3 \pm 1$ & $4.8 \pm 1$ \\
\hline BrdU labeled cells/mm epithelial cells & $333 \pm 40$ & $308 \pm 30$ & $79 \pm 24$ & $87 \pm 8$ \\
\hline \multicolumn{5}{|l|}{ Jejunum } \\
\hline Villus circumferences $(\mu \mathrm{m}) \times 10$ & $101 \pm 8$ & $96 \pm 3$ & $108 \pm 6$ & $131 \pm 12$ \\
\hline Villus heights $(\mu \mathrm{m}) \times 10$ & $40 \pm 4$ & $37 \pm 2$ & $45 \pm 3$ & $56 \pm 6$ \\
\hline Crypt depths $(\mu \mathrm{m}) \times 10$ & $25 \pm 1$ & $25 \pm 1$ & $13 \pm 1$ & $15 \pm 1$ \\
\hline Submucosa $(\mu \mathrm{m}) \times 10$ & n.d. & n.d. & $15 \pm 1$ & $12 \pm 1$ \\
\hline BrdU labeled crypt cells/total crypt cells $\times 100$ & n.d. & n.d. & $18.2 \pm 2$ & $18.3 \pm 3$ \\
\hline BrdU labeled cells/total epithelial cells × 100 & $9.7 \pm 1$ & $12.1 \pm 1$ & $7.0 \pm 1$ & $8.0 \pm 4$ \\
\hline BrdU labeled cells/mm epithelial cells & $330 \pm 40$ & $396 \pm 40$ & $123 \pm 20$ & $138 \pm 25$ \\
\hline \multicolumn{5}{|l|}{ Ileum } \\
\hline Villus circumferences $(\mu \mathrm{m}) \times 10$ & $96 \pm 5$ & $92 \pm 3$ & $107 \pm 3$ & $113 \pm 6$ \\
\hline Villus heights $(\mu \mathrm{m}) \times 10$ & $36 \pm 2$ & $34 \pm 1$ & $43 \pm 1$ & $45 \pm 3$ \\
\hline Crypt depths $(\mu \mathrm{m}) \times 10$ & $27 \pm 1$ & $26 \pm 1$ & $14 \pm 1$ & $16 \pm 1$ \\
\hline Submucosa thickness $(\mu \mathrm{m}) \times 10$ & n.d. & n.d. & $107 \pm 8$ & $105 \pm 6$ \\
\hline BrdU labeled crypt cells/total crypt cells $\times 100$ & n.d. & n.d. & $17.3 \pm 2$ & $24.1 \pm 3$ \\
\hline BrdU labeled cells/total epithelial cells $\times 100$ & $11.2 \pm 1$ & $11.4 \pm 1$ & $7.4 \pm 1$ & $10.7 \pm 1$ \\
\hline BrdU labeled cells/mm epithelial cells & $334 \pm 30$ & $350 \pm 30$ & $169 \pm 18$ & $255 \pm 18^{*}$ \\
\hline \multicolumn{5}{|l|}{ Total small intestine } \\
\hline Villus circumferences $(\mu \mathrm{m}) \times 10$ & $90 \pm 3$ & $89 \pm 4$ & $105 \pm 3$ & $120 \pm 5^{*}$ \\
\hline Villus heights $(\mu \mathrm{m}) \times 10$ & $34 \pm 2$ & $33 \pm 1$ & $43 \pm 2$ & $50 \pm 3^{*}$ \\
\hline Crypt depths $(\mu \mathrm{m}) \times 10$ & $26 \pm 1$ & $26 \pm 1$ & $13 \pm 1$ & $15 \pm 1$ \\
\hline Submucosa thickness $(\mu \mathrm{m}) \times 10$ & n.d. & n.d. & $46 \pm 10$ & $44 \pm 10$ \\
\hline BrdU labeled crypt cells/total crypt cells $\times 100$ & n.d. & n.d. & $16.1 \pm 1$ & $17.9 \pm 1$ \\
\hline BrdU labeled cells/total epithelial cells × 100 & $10.9 \pm 1$ & $11.6 \pm 1$ & $6.2 \pm 1$ & $7.8 \pm 1$ \\
\hline BrdU labeled cells/mm epithelial cells & $332 \pm 20$ & $349 \pm 20$ & $124 \pm 14$ & $160 \pm 19 \dagger$ \\
\hline \multicolumn{5}{|l|}{ Colon } \\
\hline Crypt depths $(\mu \mathrm{m}) \times 10$ & $40 \pm 2$ & $41 \pm 3$ & $27 \pm 2$ & $30 \pm 2$ \\
\hline Submucosa thickness $(\mu \mathrm{m}) \times 10$ & n.d. & n.d. & $11 \pm 2$ & $13 \pm 2$ \\
\hline BrdU labeled crypt cells/total crypt cells $\times 100$ & $7.6 \pm 1$ & $9.4 \pm 1$ & $8.5 \pm 2$ & $13.6 \pm 2.1 \dagger$ \\
\hline BrdU labeled crypt cells/mm epithelial cells & $184 \pm 40$ & $228 \pm 30$ & $144 \pm 33$ & $208 \pm 34$ \\
\hline
\end{tabular}

Values are means $\pm \mathrm{SEM}, \mathrm{n}=7$ per group.

Group differences: $\dagger=P<0.1 ; *=\mathrm{P}<0.05$.

${ }^{1}$ Cell proliferation was based on counting cells labeled with $5^{\prime}$-bromo- 2 '-deoxyuridine (BrdU).

${ }^{2}$ n.d. $=$ not done.

ileum of one calf of $\mathrm{GrC}_{2}$ and one calf of $\mathrm{GrE}$ and in duodenum of two calves of $\mathrm{GrE}$ ) postnatal small intestinal maturation processes were much progressed in most calves and were not grossly different in the experimental groups.

In agreement with other studies (Lipkin, 1981; Blättler et al., 2001), we found a negative correlation between villus height and crypt cell proliferation rate in both groups (data not shown). These data suggest that enhanced survival of intestinal epithelial cells and reduced mucosal epithelial cell death influence villus size.

Group differences. In experiment 1, there were no group differences with respect to histomorphological data or proliferation rates of crypt cells of the small intestine and colon, hence feeding hIGF-I for $7 \mathrm{~d}$ had no effects. Bühler et al. (1998), based on studies in which calves were fed Long- $\mathrm{R}^{3}$-IGF-I, found, on the other hand, a significantly higher villus height-to-crypt depth ratio. Furthermore, Baumrucker et al. (1994a) found enhanced $\left[{ }^{3} \mathrm{H}\right]$-thymidin incorporation into small intestinal cells of calves that were fed hIGF-I (750 ng/ $\mathrm{kg}$ of MR for $7 \mathrm{~d}$ ). In addition, Xu et al. (1994) described a greater DNA content in the stomach and enhanced crypt cell proliferation in small intestinal crypts of pigs fed hIGF-I but normal villus heights. Steeb et al. (1995) showed that short-term administration of s.c. injected Long-R ${ }^{3}$-IGF-I over $3 \mathrm{~d}$ ( $278 \mu \mathrm{m}$ per animal per day) in rats increased crypt depths in duodenum and jejunum, 
whereas s.c. administered recombinant IGF-I had no such effect. Furthermore, Burrin et al. (1996) found increased jejunal and ileal villus heights in neonatal pigs fed rhIGF-I (3.5 mg/kg of BW per day for $4 \mathrm{~d}$ ). Houle et al. (1997) found increased ileal villus heights in piglets fed IGF-I $(200 \mu \mathrm{m} / \mathrm{kg}$ of BW for $14 \mathrm{~d})$. In additional studies of Burrin et al. (1999), protein synthesis rates in stomach and small intestine of mouse pups suckling des(1-3) hIGF-I-enriched milk were higher than in controls. It was therefore surprising that we could not find any group differences in experiment 1 in intestinal growth and intestinal epithelial cell proliferation. The amounts of hIGF-I fed to calves of GrI were 8 to 10 times higher than the concentrations in colostrum and were therefore surely not too low to provoke morphological and proliferative effects. Reasons for these lacking effects of fed IGF-I in our experiment are unclear. There were marked differences between experimental designs, amounts of IGF-I fed, nutrition, and thus also of the matrix of the diets with which IGFI was provided to calves. In calves fed the formula, the small amounts especially of IGFBP-3 as the main binding protein also in colostrum and milk (Baumrucker and Erondu, 2000; Blum and Baumrucker, 2002) may have allowed enhanced IGF-I destruction by pancreatic, intestinal, or microbial proteases, even though the production of these enzymes was expectedly low (Guilloteau et al., 1997).

However, the probable small amounts of trypsin inhibitors in formulas may have predestined potential proteolytic IGF-I destruction. It may be that hIGF-I in the matrix of rabbit milk, although biologically active (Brem et al., 1994), behaved differently than if added in free form to milk. Thus, according to Brem et al. (1994), the fed milk of transgenic rabbits also contained IGFBP-2, a binding protein that is normally not present in high amounts in bovine colostrum (Blum and Baumrucker, 2002) and that may have changed the availability of hIGF-I at intestinal sites. However, we could not confirm the presence of IGFBP-2 in rabbit milk, in contrast to Brem et al. (1994). Western blots were performed under conditions, in which we could clearly detect IGFBP-2 and -3 and another (smaller molecular) IGFBP in plasma, IGFBP-3 in colostrum and IGFBP2 and -3 in the colostrum extract. IGFBP-3 and -2 in the formula were absent. Therefore, binding proteins in rabbit milk and formulas must have been present in only very small amounts and therefore may not have bound the large amounts of IGF-I, i.e., IGF-I may have been present in free form when provided to calves. Because IGFBP-3 and -2 were both present in colostrum extract, there were differences with respect to binding proteins fed with the formula in experiment 1 and experiment 2 . It may have been that IGFBP in colostrum extract were somehow protective for IGF-I. Furthermore, it cannot be excluded that fed IGF-I needs other regulatory factors to improve its intestinal effects and which may have been present in experiment 2 but not in experiment 1 .

In total, small intestine of experiment 2 , villus circumferences and heights as well as crypt cell proliferation rates were higher in calves fed the colostrum whey extract $(\mathrm{GrE})$ than in controls $\left(\mathrm{GrC}_{2}\right)$. Similarly, milkborne bioactive factors had significant effects on intestinal growth in methotrexate-treated rats (Howarth et al., 1996). These data indicate that the various bioactive and regulatory components, including IGF-I, in bCE exerted intestinal effects in calves, too. The data may also suggest that effects of the colostrum whey extract on intestinal tissue were due to several growth factors and bioactive substances. Effects of growth factors naturally present in colostrum may be quite different from those seen after administration of a single growth factor because of possible synergism and antagonism (Odle et al., 1996; Blum and Baumrucker, 2002). Although the effects were relatively small, they were basically in agreement with Blättler et al. (2001) who found greater villus areas and villus height-to-crypt depth ratios in jejunum of colostrum-fed calves during the first $3 \mathrm{~d}$ in comparison with formula-fed calves. The studies of Blättler et al. (2001) also showed an increased duodenal cell proliferation rate in calves that were fed colostrum for $3 \mathrm{~d}$ in comparison with formula-fed calves.

Studies of Baumrucker et al. (1994b) and Hammon and Blum (1997a) in neonatal calves have shown that the xylose absorption test is suitable to evaluate GI absorptive capacity. The absorption mainly occurs in duodenum and jejunum and the mechanism of uptake is different from that of other monosaccharides (Craig and Atkinson, 1988; Hammon and Blum, 1997a), but is dependent on a sodium-dependent glucose transporter (Scharrer and Grenacher, 2000). The lack of group differences of histomorphological and proliferation traits in experiment 1 occurred in agreement with the xylose absorption test. In experiment 2 , higher xylose concentrations in $\mathrm{GrC}_{2}$ than in $\mathrm{GrE}$ at 3 and $4 \mathrm{~h}$ after xylose feeding on $\mathrm{d} 3$ were different from experiment 1 and the above-mentioned studies, but were in accordance with a study of Baumrucker et al. (1994b), in which colostrums-fed calves at the age of 30 to $34 \mathrm{~h}$ showed smallest xylose absorptive rate and MR-fed calves showed a greater absorption rate than calves fed MR plus rhIGF-I. Differences in xylose concentration in experiment 2 may have been due to delayed GI maturation in $\mathrm{GrC}_{2}$, whereas bCE feeding may have led to a normal maturation but to a reduced absorptive capacity. 
In conclusion, whereas fed milkborne hIGF-I, derived from transgenic rabbits, did not have an effect on the intestinal tract in neonatal calves, the colostrum extract, which contained bioactive components, such as IGF-I, enhanced intestinal villus size. However, the absorptive capacity at this stage was not improved.

\section{ACKNOWLEDGMENTS}

The essential contributions in the preparation of the colostrum extract of H. Eyer (Swiss Federal Dairy Research Station, Liebefeld-Berne), who died in 2002, are fully recognized. We would like to thank C. Morel, C. Philipona and Y. Zbinden (Division of Animal Nutrition and Physiology, University of Berne, Switzerland) for their excellent laboratory work. Many thanks go to Y. Aebi, H. Schnyder and J. Sturni (Fed. Res. Station of Animal Production, Posieux) for putting the calves to our disposition. In addition, we appreciate the support by A. Waldvogel and S. Grimm of the Inst. of Animal Pathology, Univ. of Berne, Switzerland. We thank E. Husmann (UFA AG, Sursee, Switzerland) for helping us to develop the milk-based formula. The studies were supported in part by Swiss National Science Foundation (Grant Nr. 32-51012.97).

\section{REFERENCES}

Baumrucker, C. R., D. L. Hadsell, and J. W. Blum. 1994a. Effects of dietary insulin-like growth factor I on growth and insulin-like growth factor receptors in neonatal calf intestine. J. Anim. Sci. 72:428-433.

Baumrucker, C. R., M. H. Green, and J. W. Blum. 1994b. Effects of dietary rhIGF-I in neonatal calves on the appearance of glucose, insulin, d-xylose, globulins and $\gamma$-glutamyl transferase in blood. Domest. Anim. Endocrinol. 11:393-403.

Baumrucker, C. R., and N. E. Erondu. 2000. Insulin-like growth factor (IGF) system in the bovine mammary gland and milk. J. Mammary Gland Biol. Neoplasia 5:53-64.

Blättler, U., H. M. Hammon, C. Morel, C. Philipona, A. Rauprich, V. Romé, I. Le Huërou-Luron, P. Guillloteau, and J. W. Blum. 2001. Feeding colostrum, its composition and feeding duration variably modify proliferation and morphology of the intestine and digestive enzyme activities of neonatal calves. J. Nutr. 131:1256-1263.

Blum, J. W., and H. M. Hammon. 2000. Colostrum effects on the gastrointestinal tract, and on nutritional, endocrine and metabolic parameters in neonatal calves. Livest. Prod. Sci. 66:151-159.

Blum, J. W., and C. R. Baumrucker. 2002. Colostral insulin-like growth factors and related substances: mammary gland, and neonatal (intestinal and systemic) targets. Domest. Anim. Endocrinol. 23:101-110.

Brem, G., P. Hartl, U. Besenfelder, E. Wolf, N. Zinovieva, and R. Pfaller. 1994. Expression of synthetic cDNA sequences encoding human insulin-like growth factor-1 (IGF-I) in the mammary gland of transgenic rabbits. Gene 149:351-355.

Bühler, C., H. M. Hammon, G. L. Rossi, and J. W. Blum. 1998. Small intestinal morphology in eight-day-old calves fed colostrum for different duration or only milk replacer and treated with long$\mathrm{R}^{3}$-insulin-like growth factor-I and growth hormone. J. Anim. Sci. 76:758-765.

Burrin, D. G., T. J. Wester, T. A. Davis, S. Amick, and J. P. Heath. 1996. Orally administered IGF-I increases intestinal mucosal growth in formula-fed neonatal pigs. Am. J. Physiol. 270:R1085-R1091.
Burrin, D. G., M. L. Fiorotto, and D. L. Hadsell. 1999. Transgenic hypersecretion of des(1-3) human insulin-like growth factor I in mouse milk has limited effects on the gastrointestinal tract in suckling pups. J. Nutr. 129:51-56.

Campana, W. M., and C. R. Baumrucker. Hormones and growth factors in bovine milk. 1995. Pages 476-494 in Handbook of Milk Composition. R. G. Jensen, ed. Academic Press, San Diego, CA.

Cordano, P., H. M. Hammon, and J. W. Blum. 1998. Tissue distribution of insulin-like growth factor-I mRNA in 8-day old calves. Page 288 in Proc. Symp. Growth in Ruminants. J. W. Blum, T. Elsasser, and P. Guilloteau, eds. University of Berne, Berne, Switzerland.

Cordano, P., H. M. Hammon, C. Morel, A. Zurbriggen, and J. W. Blum. 2000. Messenger RNA of insulin-like growth factor (IGF) quantification and presence of IGF binding proteins, and receptors for growth hormone, IGF-I and insulin, determined by reverse-transcribed polymerase chain reaction, in the liver of growing and mature male cattle. Domest. Anim. Endocrinol. 19:191-208.

Craig, R. M., and A. J. Atkinson. 1988. D-Xylose testing: a review. Gastroenterology 95:223-231.

Erhard, M. H., U. Lscher, and M. Stangassinger. 1995. Untersuchungen zur intestinalen Absorption von homologem und heterologem Immunglobulin G bei neugeborenen Kälbern. Z. Ernährungswiss. 34:160-163.

Georgiev, I. P., T. M. Georgieva, M. Pfaffl, H. M. Hammon, and J. W. Blum. 2003. Insulin-like growth factor and insulin receptors in intestinal mucosa of neonatal calves. J. Endocrinol. 176:121-132.

Guilloteau, P., I. Le Huërou-Luron, R. Toullec, J. A. Chayvialle, R. Zabielski, and J. W. Blum. 1997. Gastrointestinal regulatory peptides and growth factors in young cattle and sheep. J. Vet. Med. A $44: 1-23$.

Hadorn, U., H. M. Hammon, R. M. Bruckmaier, and J. W. Blum. 1997. Delaying colostrum intake by one day has important effects on metabolic traits and on gastrointestinal and metabolic hormones in neonatal calves. J Nutr. 127:2011-2023.

Hammon, H. M., and J. W. Blum. 1997a. Prolonged colostrum feeding enhances xylose absorption in neonatal calves. J. Anim. Sci. 75:2915-2919.

Hammon, H. M., and J. W. Blum. 1997b. The somatotropic axis in neonatal calves can be modulated by nutrition, growth hormone and Long- R3-IGF-I. Am. J. Physiol. 273:E130-E138.

Hammon, H. M., and J. W. Blum. 2002. Feeding different amounts of colostrum or only milk replacer modify receptors of intestinal insulin-like growth factors and insulin in neonatal calves. Domest. Anim. Endocrinol. 22:155-168.

Houle, V. M., E. A. Schroeder, J. Odle, and S. M. Donovan. 1997. Small intestinal disaccharidase activity and ileal villus height are increased in piglets consuming formula containing recombinant human insulin-like growth factor-I. Pediatr. Res. 42:78-86.

Howarth, G. S., G. L. Francis, J. C. Cool, X. Xu, R. W. Byard, and L. C. Read. 1996. Milk growth factors enriched from cheese whey ameliorate intestinal damage by methotrexate when administered orally to rats. J. Nutr. 126:2519-2530.

Lipkin, M. 1981. Proliferation and differentiation of gastrointestinal cells in normal and disease states. Pages 145-168 in Physiology of the Gastrointestinal Tract. L. R. Johnson, ed. Raven Press, New York.

Odle, J., R. T. Zijlstra, and S. M. Donovan. 1996. Intestinal effects of milkborne growth factors in neonates of agricultural importance. J. Anim. Sci. 74:2509-2522.

Pácha, J. 2000. Development of intestinal transport function in mammals. Physiol. Rev. 80:1633-1667.

Pfaffl, M. W., T. M. Georgieva, I. P. Georgiev, E. Ontsouka, E. Hageleit, and J. W. Blum. 2002. Real-time RT-PCR quantification of insulin-like growth factor (IGF)-1, IGF-1 receptor, IGF-2, IGF-2 receptor, insulin receptor, growth hormone receptor, IGF-binding proteins 1, 2 and 3 in the bovine species. Domest. Anim. Endocrinol. 22:91-102.

Rauprich, A. B. E., H. M. Hammon, and J. W. Blum. 2000. Effects of feeding colostrum and a formula with nutrient contents as 
colostrum on metabolic and endocrine traits in neonatal calves. Biol. Neonate. 78:53-64.

Sangild, P. T. 2001. Transitions in the life of the gut at birth. Pages 3-17 in Digestive Physiology of Pigs. J. E. Lindberg and B. Ogle, eds. CABI Publishing, Oxon and New York.

SAS. 1996. User's Guide: Statistics, Version 6.12. SAS inst Inc, Cary, NC.

Scharrer, E., and B. Greenacher. 2000. Na+-dependent transport of $\mathrm{D}$-xylose by bovine intestinal brush border membrane vesicles (BBMV) is inhibited by various pentoses and hexoses. J. Vet. Med. A 47:617-626.

Steeb, C. B., J. F. TrahairF, and L. C. Read. 1995. Administration of insulin-like growth factor-I (IGF-I) peptides for three days stimulates proliferation of the small intestinal epithelium in rats. Gut 37:630-638.

Vacher, P. Y., G. Bestetti, and J. W. Blum. 1995. Insulin-like growth factor-I absorption in the jejunum of neonatal calves. Biol. Neonate. 68:354-367.

Wolf, E., P. M. Jehle, M. M. Weber, H. Sauerwein, A. Daxenberger, B. H. Breier, U. Besenfelder, L. Frenyo, and G. Brem. 1997. Human insulin-like growth factor I (IGF-I) produced in the mammary glands of trangenic rabbits: yield, receptor binding, mitogenic activity, and effects on IGF-binding proteins. Endocrinol. 138:307-313.

Xu, R. J., D. J. Mellor, M. J. Birtles, B. H. Breier, and P. D. Gluckman. 1994. Effects of oral IGF-I or IGF-II on digestive organ growth in newborn piglets. Biol. Neonate. 66:280-287. 